\title{
Growth and Grain Yield of Pearl Millet (Pennisetum glaucum) Genotypes at Different Levels of Nitrogen Fertilization in the Southeastern United States
}

\author{
Eric Obeng ${ }^{1}$, Ernst Cebert ${ }^{1}$, Bharat P. Singh ${ }^{2}$, Rufina Ward ${ }^{1}$, Leopold M. Nyochembeng ${ }^{1} \&$ David A. Mays ${ }^{1}$ \\ ${ }^{1}$ Alabama A \& M University, Department of Biological \& Environmental Sciences, 4900 Meridian Street, USA \\ ${ }^{2}$ Fort Valley State University, 1005 State University Drive, Fort Valley, Georgia 31030, USA \\ Correspondence: Ernst Cebert, Alabama A \& M University, Department of Biological \& Environmental Sciences, \\ 4900 Meridian Street, USA. Tel: 1-256-372-4243. E-mail: ernst.cebert@aamu.edu
}

\author{
Received: August 9, 2012 Accepted: August 27, 2012 Online Published: November 15, 2012 \\ doi:10.5539/jas.v4n12p155 URL: http://dx.doi.org/10.5539/jas.v4n12p155
}

\begin{abstract}
Pearl millet (Pennisetum glaucum [L.] R. Br) has the requisite characteristics for dry land production in the southeastern USA in comparison to the traditional grain crops while requiring less input. The purpose of this study was to identify the genotypes that produce the highest yield and seed quality at different rates of nitrogen. Four pearl millet genotypes $(2304, \mathrm{LHB} 08,606 \mathrm{~A} 1 * 2304$ and 707A1*4280) were cultivated on secondary land and treated with 4 different nitrogen rates: $0,40,80$ and $120 \mathrm{~kg} \mathrm{ha}^{-1}$. The genotypes were evaluated for agronomic parameters including booting, number of tillers, plant height, plant weight, number of heads, head length and yield. Nitrogen rate did not have any significant effect on the head length, number of tillers and plant (dry) weight among the genotypes. Plant height ranged between 96 and $111 \mathrm{~cm}$ and was significantly different among the genotypes. However, numerically, genotype LHB08 produced the longest heads $(42 \mathrm{~cm})$ and highest seed yield $\left(6,159 \mathrm{~kg} \mathrm{ha}^{-1}\right)$ across all treatments. Overall, nitrogen rate did not produce significant difference in yield among the genotypes. Since grain yield obtained in this study is comparable to those reported elsewhere, it can be inferred that pearl millet has the potential as a new grain crop for the southeastern United States. Furthermore, results demonstrated that pearl millet can be grown with limited N-input. As N-fertilization is the major cost of producing any crop, pearl millet offers special opportunity for large number of limited resource farmers in the region.
\end{abstract}

Keywords: dry land, pearl millet growth, yield and Nitrogen fertilization

\section{Introduction}

Pearl millet is the sixth most important cereal in the world after wheat (Triticumaestivum), rice (Oryza sativa), maize (Zea mays L.), barley (Hordeumvulgare) and sorghum (Sorghum bicolor) (Singh, Singh, \& Tyagi, 2003; Henry \& Kettlewell, 1996). It is a major crop in the semi-arid dry land regions in Southeast Asia and Africa (Baltensperger, 2002). In the United States, pearl millet is grown as a summer annual forage crop, as seed for the bird feed industry and for wildlife. Increasingly, it is being regarded as an alternative feed grain for poultry (Timper \& Hanna, 2005). Pearl millet possesses the unique genetic predisposition to withstand environmental stress and produce appreciable yield when grown on marginal soils. Because of these favorable characteristics, pearl millet has been projected as a potential feedstock for biofuels (Wilson et al., 2006). Improving crop performance to obtain appreciable economic yields requires a clear understanding of the crop including management of nutrients during the production cycle for newly developed cultivars.

Realizing the multiple use potential of pearl millet grain, several research projects are underway to develop new pearl millet varieties and hybrids for high grain yield. Agronomic variations among pearl millet genotypes have been reported earlier by Khairwal et al. (2007), which may serve as a guide for breeding and selection depending on the purpose for which pearl millet is being grown, such as for forage (Sedivec \& Schatz, 1991) or as a grain (Dewey et al., 2009). Research on pearl millet for grain has been centered on developing dwarf hybrids (Rajewski \& Andrews, 1995), proper row spacing (Pale, 2002), controlling weeds (Limon-Ortega, Mason, \& Martin, 1998), date of planting (Pale et al., 2003) and adaptability to local conditions (Maman, Lyon, Mason, Galusha, \& Higgins, 2003). The tall hybrids are high yielding while the dwarf varieties are excellent for grazing 
but with lower grain yields (Hancock, 2009). Several limiting nutrients, including nitrogen (N), potassium (K) and phosphorous $(\mathrm{P})$, reduce the optimum performance of grain production. According to Pandey, Maranville, \& Bako (2001), $\mathrm{N}$ is considered the most important limiting nutrient for many economically important crops. Nitrogen use efficiency (NUE) of pearl millet is higher than many other crops (Muchow, 1988) because increasing the rate of $\mathrm{N}$ fertilization does not always accompany a corresponding increase in grain yield.

Pearl millet is well suited for the southeastern US climate and soil characteristics. It is the second most popular type of summer annual grass in Alabama and is mostly used for grazing or hay (Baker, 1993; Davis, Dale, \& Ferreira, 2003; Sedivec \& Schatz, 1991). Mullins and Reeves (1994) reported pearl millet grain yields exceeding $5,700 \mathrm{~kg} \mathrm{ha}^{-1}$ in slightly acidic soil condition with high residual phosphorus in southern Alabama. Grain and biomass yield of 5.3 and $16.7 \mathrm{Mg} \mathrm{ha}^{-1}$, respectively have been reported in Nebraska (Maman et al., 2003). Therefore, pearl millet in rotation with other crops such as wheat and canola, or if grown on non prime agricultural lands can supply both seeds and biomass as feedstock for biofuels, and serve as a supplement to maize. The objective of this study was to determine the response of four (4) of the most promising and advanced type grain lines of pearl millet available at the USDA-ARS (United States Department of Agriculture, Agricultural Research Service) Pearl Millet Breeding Program, Tifton, Georgia to different rates of N-Fertilization under environmental conditions in southeastern United States.

\section{Materials and Methods}

During the growing seasons of 2009 and 2010, pearl millet production experiments were conducted at the Winfred Thomas Agricultural Research Station of Alabama A\&M University in Hazel Green, Alabama (latitude: $34^{\circ} 54^{\prime} 57.6^{\prime \prime}$, longitude: $86^{\circ} 38^{\prime} 49.6^{\prime \prime}$, elevation: 248.1 meters on a Decatur silty clay loam soil (Clayey, Kaolinitic, and thermic RhodicPaleudults). Four pearl millet lines $(2304$, LHB08, 606A1*2304 and 707A1*4280) with wide genetic variability were selected for this study by the pearl millet breeder at the Crop Genetics and Breeding Research Unit, USDA-ARS, Tifton, Georgia. Two of the lines, 2304 and LHB08, are open pollinated inbreds, while the other two lines, 606A1*2304 and 707A1*4280, are hybrids. These four lines were used in this study to evaluatepearl millet response to $\mathrm{N}$ fertilization rates of $0,40,80$ and $120 \mathrm{~kg} \mathrm{ha}^{-1}$ as well as for genotype $\mathrm{x} \mathrm{N}$ rate variations. The seeds were planted on June $4^{\text {th }}$ and June $7^{\text {th }}$ for 2009 and 2010, respectively. For both seasons, the land was appropriately prepared two days prior to planting. Seeds were sown at a rate of $5 \mathrm{~kg} \mathrm{ha}^{-1}$ on plots measuring $3.05 \mathrm{~m}$ x $1.14 \mathrm{~m}$. The plots were arranged in a Randomized Complete Block Design (RCBD) with four replications. Ammonium nitrate fertilizer (34-0-0; $\left.\mathrm{NH}_{4} \mathrm{NO}^{3-}-\mathrm{P}-\mathrm{K}\right)$ treatments was applied to appropriate plots manually after crop establishment. Experimental plots were rain-fed and weeds were removed manually throughout the growing season.

Pre-harvest data collected included plant stand (number of plants per plot), number of plants booting at different dates, plant height and seeding development (percentage seed formed in relationship to head length). At maturity, 5 randomly selected plants per plot and post-harvest agronomic data were taken for number of tillers per plant, head length, vegetative dry weight and seed weight. The plots were harvested to estimate grain yield.

Data were analyzed using general Analysis of Variance (ANOVA) procedure in General Linear Model (GLM) to determine statistical significance. Means were separated using Duncan's Multiple Range Test at $\mathrm{p}=0.05$. Correlation was also carried out based on statistical significance. Statistical Analysis System (SAS) package ver. 9.2 was used for all analyses.

\section{Results and Discussion}

\subsection{Tillering}

According to Andrews, Majumdar and\& Doggett (1975) there are three types of tillering in pearl millet: synchronous, non-synchronous basal tillering and sub-terminal tillering. With sub-terminal tillering, the tillers arise from the auxiliary buds, whereas in the synchronous and non-synchronous tillering, the tillers arise from the basal leaf bud axils. Based on the sub-terminal tillers, genotype 606A1 x 2304 produced significantly more tillers than all the other genotypes for both 2009 and 2010. Number of tillers for all the four nitrogen rates in both 2009 and 2010 did not differ significantly (Table 1). In 2009, wetter (precipitation $13.0 \mathrm{~cm}$ during the growing period) and warmer (mean temperature of $18^{\circ} \mathrm{C}$ ) growing conditions resulted in more tillers, the order of tiller number for the four lines being in the following order: 606A $1 * 2304>707 \mathrm{~A} 1 * 4280>$ LHBO8 $>2304$. In 2010, with total precipitation during growing season of $8.0 \mathrm{~cm}$ and mean temperature of $17.5^{\circ} \mathrm{C}$, genotype $606 \mathrm{~A} 1 * 2304$ produced the maximum number of tillers, 2304 the second largest, followed by LHBO 8 and $707 \mathrm{~A} 1 * 4280$ (Table 1). It was clear from the difference in the tiller number count between the two years that rainfall during the period of tiller formation significantly affected the total tiller number formed by the plant. 
Table 1. Averages for head length, number of heads, number of tillers, plant weight and grain yield for four Pearl millet genotypes and four nitrogen rates

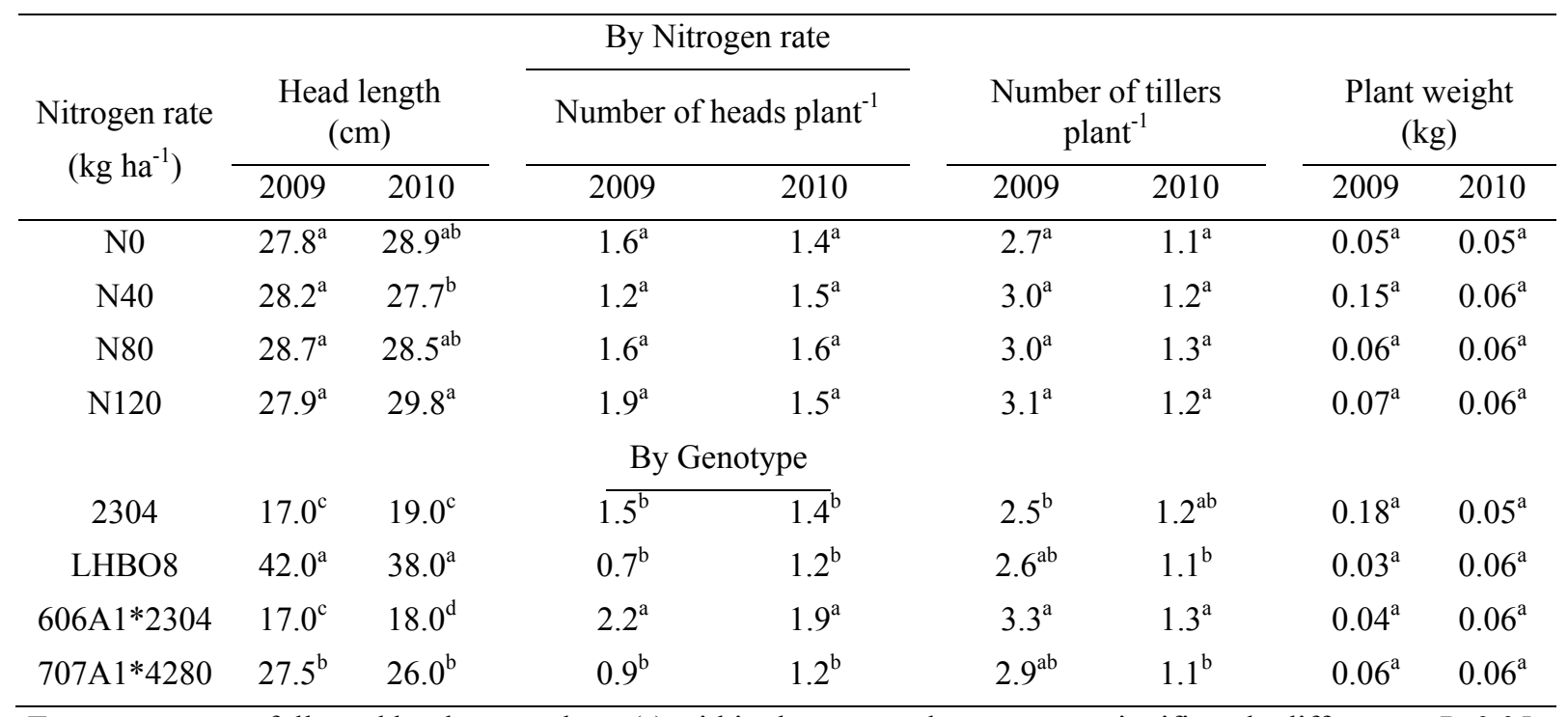

Treatment means followed by the same letter(s) within the same column are not significantly different at $P \leq 0.05$.

The onlysignificant interaction observed was between genotype $606 \mathrm{~A} 1 * 2304$ and $80 \mathrm{~kg} \mathrm{ha}^{-1}$ that produced greater number of tillers per plant than other $\mathrm{N}$ levels. The other interactions of genotypes LHBO8, 707A $1 * 4280$, $606 \mathrm{~A} 1 * 2304$ and 2304 with $0,40,80$ and $120 \mathrm{~kg} \mathrm{ha}^{-1} \mathrm{~N}$ did not show any significant statistical difference in the number of tillers in 2009 and 2010 (Table 2). However, it was noted that tiller progression and transition into the reproductive growth stage was closely related to the timing of its emergence. Largest heads resulted from tillers which emerged earliest in comparison to smaller heads derived from late emerging tillers. A similar observation was reported in rice by Raghunatha, Jagannath, Krishnamurthy, and Rajashekara (1972) that early appearing tillers produce larger heads.

Table 2. Averages for head length, number of heads, number of tillers and plant dry weight for four Pearl millet genotypes and their interaction with four nitrogen rates

\begin{tabular}{|c|c|c|c|c|c|c|c|c|}
\hline \multirow{2}{*}{ Genotype x Nitrogen Rate } & \multicolumn{2}{|c|}{ Head length $(\mathrm{cm})$} & \multicolumn{2}{|c|}{ Number of heads } & \multicolumn{2}{|c|}{ Number of tillers } & \multicolumn{2}{|c|}{ Plant weight (kg) } \\
\hline & 2009 & 2010 & 2009 & 2010 & 2009 & 2010 & 2009 & 2010 \\
\hline $2304 \times$ N0 & $22.00^{\mathrm{d}}$ & $22.50^{\mathrm{de}}$ & $1.7^{\mathrm{cd}}$ & $1.7^{\text {bcde }}$ & $2.7^{\mathrm{ab}}$ & $1.2^{\mathrm{abc}}$ & $0.16^{\mathrm{a}}$ & $0.08^{\mathrm{ab}}$ \\
\hline $2304 \times$ N40 & $19.50^{\mathrm{d}}$ & $22.50^{\mathrm{de}}$ & $1.3^{\mathrm{cd}}$ & $1.6^{\mathrm{cde}}$ & $2.5^{\mathrm{ab}}$ & $1.0^{\mathrm{abc}}$ & $0.14^{\mathrm{a}}$ & $0.04^{\mathrm{ab}}$ \\
\hline $2304 \times$ N80 & $21.00^{\mathrm{d}}$ & $21.50^{\mathrm{de}}$ & $1.2^{\mathrm{d}}$ & $1.4^{\text {cde }}$ & $1.6^{\mathrm{a}}$ & $1.1^{\mathrm{abc}}$ & $0.09^{\mathrm{a}}$ & $0.04^{\mathrm{b}}$ \\
\hline $2304 \times$ N 120 & $16.00^{\mathrm{d}}$ & $24.50^{\mathrm{d}}$ & $2.3^{\mathrm{bcd}}$ & $1.8^{\text {abcde }}$ & $2.6^{\mathrm{ab}}$ & $1.2^{\mathrm{abc}}$ & $0.09^{\mathrm{a}}$ & $0.08^{\mathrm{ab}}$ \\
\hline LHBO $8 \times$ N0 & $46.50^{\mathrm{a}}$ & $42.00^{\mathrm{a}}$ & $1.3^{\mathrm{cd}}$ & $1.2^{\mathrm{de}}$ & $2.1^{\mathrm{ab}}$ & $1.0^{\mathrm{bc}}$ & $0.08^{\mathrm{a}}$ & $0.07^{\mathrm{ab}}$ \\
\hline LHBO8 x N40 & $49.00^{\mathrm{a}}$ & $37.00^{\mathrm{bc}}$ & $1.4^{\mathrm{cd}}$ & $1.4^{\text {cde }}$ & $3.0^{\mathrm{ab}}$ & $1.1^{\mathrm{abc}}$ & $0.09^{\mathrm{a}}$ & $0.09^{\mathrm{ab}}$ \\
\hline LHBO8 x N80 & $37.00^{\mathrm{b}}$ & $40.00^{\mathrm{ab}}$ & $1.7^{\mathrm{cd}}$ & $1.6^{\mathrm{cde}}$ & $2.6^{\mathrm{ab}}$ & $1.3^{\mathrm{abc}}$ & $0.08^{\mathrm{a}}$ & $0.07^{\mathrm{ab}}$ \\
\hline LHBO8 x N120 & $47.00^{\mathrm{a}}$ & $42.00^{\mathrm{a}}$ & $1.8^{\mathrm{cd}}$ & $1.1^{\mathrm{e}}$ & $2.6^{\mathrm{ab}}$ & $1.0^{\mathrm{bc}}$ & $0.07^{\mathrm{a}}$ & $0.07^{\mathrm{ab}}$ \\
\hline $606 \mathrm{~A} 1 * 2304 \times \mathrm{N} 0$ & $18.00^{\mathrm{d}}$ & $19.00^{\mathrm{e}}$ & $2.5^{\mathrm{abc}}$ & $2.2^{\mathrm{ab}}$ & $3.1^{\mathrm{ab}}$ & $1.3^{\mathrm{abc}}$ & $0.07^{\mathrm{a}}$ & $0.06^{\mathrm{b}}$ \\
\hline $606 \mathrm{~A} 1 * 2304 \times \mathrm{N} 40$ & $17.50^{\mathrm{d}}$ & $22.50^{\mathrm{de}}$ & $2.2^{\mathrm{bcd}}$ & $2.0^{\mathrm{abc}}$ & $2.5^{\mathrm{ab}}$ & $1.1^{\mathrm{abc}}$ & $0.07^{\mathrm{a}}$ & $0.08^{\mathrm{ab}}$ \\
\hline $606 \mathrm{~A} 1 * 2304 \times \mathrm{N} 80$ & $22.00^{\mathrm{d}}$ & $21.50^{\mathrm{de}}$ & $3.5^{\mathrm{a}}$ & $2.3^{\mathrm{a}}$ & $3.5^{\mathrm{a}}$ & $1.5^{\mathrm{a}}$ & $0.07^{\mathrm{a}}$ & $0.10^{\mathrm{ab}}$ \\
\hline $606 \mathrm{~A} 1 * 2304$ x N120 & $21.50^{\mathrm{d}}$ & $18.50^{\mathrm{e}}$ & $3.2^{\mathrm{a}}$ & $1.8^{\mathrm{abcd}}$ & $3.5^{\mathrm{a}}$ & $1.2^{\mathrm{abc}}$ & $0.06^{\mathrm{a}}$ & $0.06^{\mathrm{ab}}$ \\
\hline $707 \mathrm{~A} 1 * 4280 \times \mathrm{N} 0$ & $29.00^{\mathrm{c}}$ & $26.00^{\mathrm{d}}$ & $1.5^{\mathrm{cd}}$ & $1.2^{\mathrm{de}}$ & $2.3^{\mathrm{ab}}$ & $0.9^{\mathrm{c}}$ & $0.06^{\mathrm{a}}$ & $0.10^{\mathrm{ab}}$ \\
\hline $707 \mathrm{~A} 1 * 4280 \times \mathrm{N} 40$ & $30.00^{\mathrm{c}}$ & $25.00^{\mathrm{d}}$ & $2.0^{\mathrm{cd}}$ & $1.7^{\text {bcde }}$ & $2.8^{\mathrm{ab}}$ & $1.5^{\mathrm{ab}}$ & $0.30^{\mathrm{a}}$ & $0.07^{\mathrm{ab}}$ \\
\hline $707 \mathrm{~A} 1 * 4280 \times \mathrm{N} 80$ & $33.00^{\mathrm{b}}$ & $25.50^{\mathrm{d}}$ & $1.4^{\mathrm{cd}}$ & $1.3^{\mathrm{de}}$ & $3.1^{\mathrm{ab}}$ & $1.1^{\mathrm{abc}}$ & $0.03^{\mathrm{a}}$ & $0.06^{\mathrm{ab}}$ \\
\hline $707 \mathrm{~A} 1 * 4280 \times \mathrm{N} 120$ & $32.00^{\mathrm{bc}}$ & $33.50^{\mathrm{c}}$ & $2.2^{\mathrm{bcd}}$ & $1.9^{\mathrm{abcd}}$ & $3.0^{\mathrm{ab}}$ & $1.3^{\mathrm{ab}}$ & $0.02^{\mathrm{a}}$ & $0.11^{\mathrm{a}}$ \\
\hline
\end{tabular}

Treatment means followed by the same letter(s) within the same column are not significantly different at $P$ $\leq 0.05$. 


\subsection{Head Length}

There was no significant difference in head length for all the four nitrogen rates in 2009, but in 2010 differences existed between 40 and $120 \mathrm{~kg} \mathrm{ha}^{-1} \mathrm{~N}$ (Table 1). However, the difference in head length between $\mathrm{N} 40$ and N120 appears to be an aberration because while a decline occurred from $0 \mathrm{~N}$ to $40 \mathrm{~N}$, head length again became similar between $0 \mathrm{~N}$ and $80 \mathrm{~N}$ and $0 \mathrm{~N}$ and $120 \mathrm{~N}$. This result is in contrast to the observation by Maas and Hanna (2006), whereby an increase in nitrogen rate of up to $112 \mathrm{~kg} \mathrm{ha}^{-1}$ led toa boost in head length. Genotypes were easily separable into three separate categories based on head size: 1) shortest head- 2304 and 606A $1 * 2304,2$ ) intermediate head- 707A1*4280, and 3) longest head- LHBO8. Head length for both years ranged between 20.7 and $48.1 \mathrm{~cm}$. Teare, Wright, and Pudelko (1994) has emphasizedof head length being the primary factor in pearl millet productivity.

\subsection{Number of Heads}

The number of heads and head length has been found to be positively correlated to grain yield (Singh, 1969; Pudelko, Wright, \& Teare, 1993). Nitrogen rates $0 \mathrm{~kg} \mathrm{ha}^{-1}, 40 \mathrm{~kg} \mathrm{ha}^{-1}, 80 \mathrm{~kg} \mathrm{ha}^{-1}$ and $120 \mathrm{~kg} \mathrm{ha}^{-1}$ did not show any significant difference for number of heads for both years (Table 1). The number of heads at the time of harvest for genotypes 2304 , LHBO 8 and $707 \mathrm{~A} 1 * 4280$ was not statistically different, but there was a significant difference between these three genotypes and 606A $1 * 2304$; the latter produced the highest number of heads per plant both in 2009 and 2010 (Table 1). Genotype 606A1*2304 which produced the highest number of heads, also had the highest tiller density. The interaction of genotype 606A1*2304 and all the four nitrogen rates performed better than their competitors, and overall, genotype 606A1 x 2304 at nitrogen rate $80 \mathrm{~kg} \mathrm{ha}^{-1}$ had the maximum number of heads (Table 2).

\subsection{Plant Height}

In 2010, the highest rate of $120 \mathrm{~kg} \mathrm{ha}^{-1}$ nitrogen produced the tallest plants at 56 DAP. Plant heights at nitrogen rates 40 and $80 \mathrm{~kg} \mathrm{ha}^{-1}$ were not significantly different at 56 DAP. At $105 \mathrm{DAP}$; plant height for the four nitrogen rates did not differ statistically among the treatments (Figure 1). These results are consistent with the findings by Maas, Hanna, and Mullinix (2007), in which plant height did not differ for nitrogen rates.

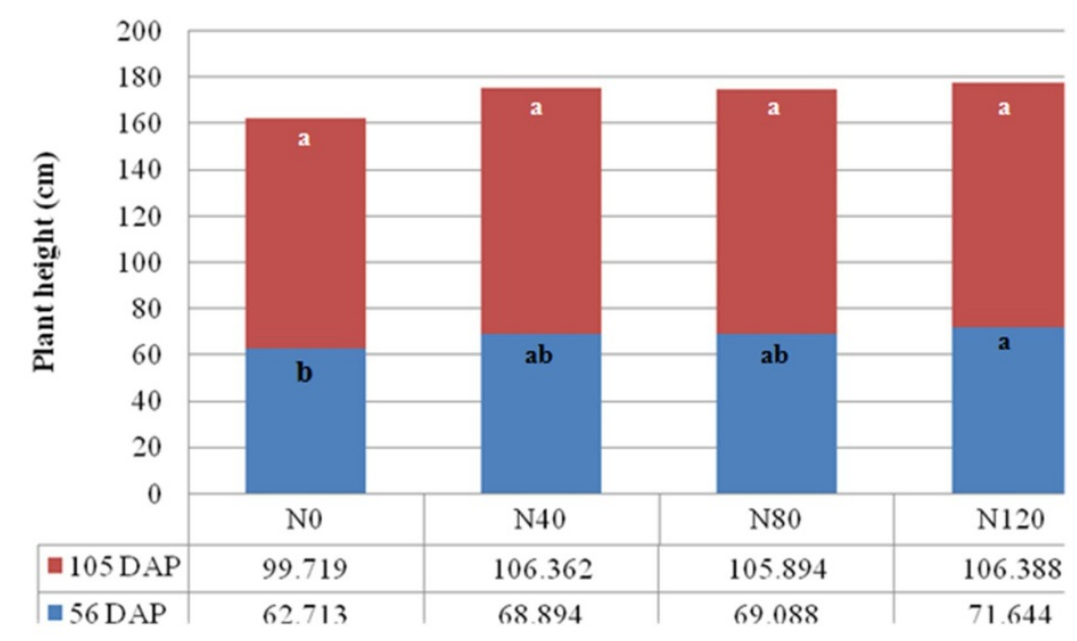

Figure 1. Average plant height for four pearl millet genotypes in response to four nitrogen rates at 56 and $105 \mathrm{DAP}$ in 2010

Plant height measured before booting and at maturity showed significant variation among the genotypes. Average plant height at 56 days after planting (DAP) during the first year showed the following sequence from tall to short: $2304>606 \mathrm{~A} 1 * 2304>\mathrm{LHBO} 8>707 \mathrm{~A} 1 * 4280$. At $105 \mathrm{DAP}$, the sequence of cultivars for height shifted to LHBO8> 2304>707A $1 * 4280>606 \mathrm{~A} 1 * 2304$ from tallest to lowest. Genotype 606A1*2304 produced the highest number of tillers (Table 1) on average but plants were short (Figure 2), a characteristic that may be a desirable for grazing and mechanized harvesting. 


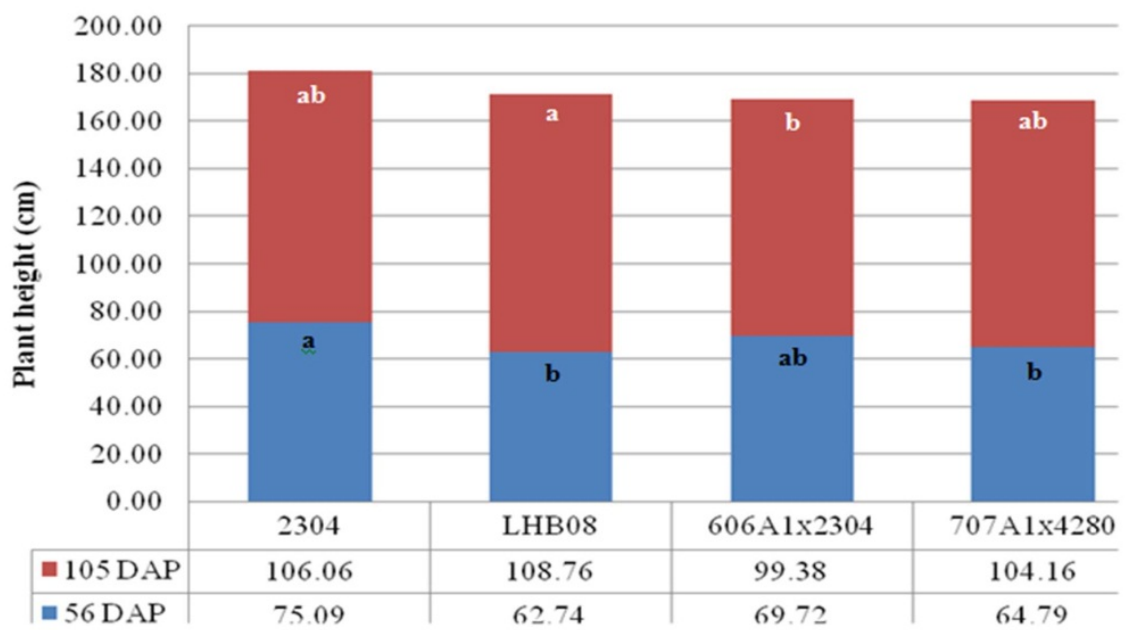

Figure 2. Average plant height of four pearl millet genotypes in response to four nitrogen rates at 56 and $105 \mathrm{DAP}$ in 2009

There was a negative correlation between the number of tillers and plant height in all genotypes, which is similar to findings by Tchala (1989). Plant height at 63 and 77 DAP were positively correlated. Plant height at 49,63 and 77 days after planting had a direct correlation with grain yield produced (Table 3 ); the taller the plants, the higher the yield. Among the test cultivars, plant height was consistent during the growth process; however, differences in height at harvest were due to head length.

Table 3. Plant height, number of plants booting and estimated yield for four genotypes of pearl millet treated with four nitrogen rates

\begin{tabular}{|c|c|c|c|c|c|}
\hline $\begin{array}{l}\text { Genotype x Nitrogen } \\
\text { Rate }\end{array}$ & $\begin{array}{l}\text { Plant height at } 56 \\
\text { DAP }(\mathrm{cm})\end{array}$ & $\begin{array}{l}\text { Heads booting at } \\
63 \text { DAP }\end{array}$ & $\begin{array}{l}\text { Plant height } \\
\text { at } 105 \text { DAP } \\
(\mathrm{cm})\end{array}$ & $\begin{array}{l}\text { Head length } \\
(\mathrm{cm})\end{array}$ & $\begin{array}{l}\text { Estimated Yield (kg } \\
\mathrm{ha}^{-1} \text { ) }\end{array}$ \\
\hline $2304 \times \mathrm{N} 0$ & $69.9^{\mathrm{abcd}}$ & $8.0^{\mathrm{cd}}$ & $96.5^{\mathrm{b}}$ & $23.00^{\mathrm{de}}$ & $1314.7^{\text {defg }}$ \\
\hline $2304 \times \mathrm{N} 40$ & 78. $1^{\mathrm{abc}}$ & $11.5^{\mathrm{bcd}}$ & $111.1^{\mathrm{ab}}$ & $22.5^{\mathrm{de}}$ & $808.6^{\mathrm{efg}}$ \\
\hline 2304 x N80 & $69.9^{\mathrm{abcd}}$ & $10.8^{\mathrm{bcd}}$ & $105.4^{\mathrm{ab}}$ & $22.00^{\mathrm{de}}$ & $979.7^{\mathrm{etg}}$ \\
\hline 2304 x N120 & $82.6^{\mathrm{a}}$ & $17.5^{\mathrm{abc}}$ & $111.2^{\mathrm{ab}}$ & $19.00^{\mathrm{d}}$ & $1305.7^{\text {defg }}$ \\
\hline LHB08 x N0 & $64.1^{\mathrm{bcd}}$ & $3.8^{\mathrm{d}}$ & $105.5^{\mathrm{ab}}$ & $42.00^{\mathrm{a}}$ & $6226.4^{\mathrm{ab}}$ \\
\hline LHB08 x N40 & $66.7^{\mathrm{abcd}}$ & $6.8^{\mathrm{cd}}$ & $104.8^{\mathrm{ab}}$ & $36.50^{b c}$ & $6386.3^{\mathrm{ab}}$ \\
\hline LHB08 x N80 & $62.3^{\mathrm{dc}}$ & $6.3^{\mathrm{cd}}$ & $118.8^{\mathrm{a}}$ & $40.00^{\mathrm{ab}}$ & $4805.1^{\mathrm{bc}}$ \\
\hline LHB08 x N120 & $57.9^{d}$ & $10.3^{\mathrm{cd}}$ & $106.1^{\mathrm{ab}}$ & $42.00^{\mathrm{a}}$ & $7218.9^{\mathrm{a}}$ \\
\hline $606 \mathrm{~A} 1 * 2304 \times \mathrm{N} 0$ & $62.2^{\mathrm{dc}}$ & $11.3^{\mathrm{bcd}}$ & $98.4^{\mathrm{b}}$ & $19.00^{\mathrm{e}}$ & $562.2^{\mathrm{g}}$ \\
\hline $606 \mathrm{~A} 1 * 2304 \times \mathrm{N} 40$ & $66.7^{\mathrm{abcd}}$ & $15.0^{\mathrm{abcd}}$ & $102.2^{\mathrm{ab}}$ & $23.00^{\mathrm{de}}$ & $496.0^{\mathrm{g}}$ \\
\hline $606 \mathrm{~A} 1 * 2304 \times \mathrm{N} 80$ & $82.6^{\mathrm{a}}$ & $26.0^{\mathrm{a}}$ & $97.8^{\mathrm{b}}$ & $21.50^{\mathrm{de}}$ & $1190.7^{\text {efg }}$ \\
\hline $606 \mathrm{~A} 1 * 2304$ x N120 & $67.4^{\mathrm{abcd}}$ & $22.8^{\mathrm{ab}}$ & $99.1^{\mathrm{ab}}$ & $21.00^{\text {de }}$ & $1036.8^{\text {efg }}$ \\
\hline $707 \mathrm{~A} 1 * 4280 \times \mathrm{N} 0$ & $54.6^{\mathrm{d}}$ & NA & $98.5^{\mathrm{b}}$ & $26.50^{d}$ & $2801.7^{\text {cdef }}$ \\
\hline $707 \mathrm{~A} 1 * 4280 \times \mathrm{N} 40$ & $64.1^{\mathrm{bcd}}$ & NA & $107.3^{\mathrm{ab}}$ & $25.00^{\mathrm{d}}$ & $3063.4^{\mathrm{cd}}$ \\
\hline $707 \mathrm{~A} 1 * 4280 \times \mathrm{N} 80$ & $61.7^{\mathrm{d}}$ & NA & $101.6^{\mathrm{ab}}$ & $26.00^{\mathrm{d}}$ & $3598.1^{\mathrm{c}}$ \\
\hline $707 \mathrm{~A} 1 * 4280 \times \mathrm{N} 120$ & $78.8^{\mathrm{ab}}$ & $2.3^{\mathrm{d}}$ & $109.3^{\mathrm{ab}}$ & $34.00^{\mathrm{c}}$ & $3394.4^{\mathrm{cd}}$ \\
\hline
\end{tabular}

Treatment means followed by the same letter(s) within the same column are not significantly different at $P \leq 0.05$.

\subsection{Plant Weight}

According to Chohan, Naeem, Khan, \& Kainth (2006), tall genotypes produce higher fodder than shorter ones. Mean plant dry weight for the four genotypes was not significantly different for both 2009 and 2010 (Table 1). 
Statistically four nitrogen rates used did not result in any difference in plant weight for both years. This indicates that nitrogen rate had no direct effect on plant biomass of four pearl millet genotypes used in this study. During the 2009 growing season, there was no significant difference in plant dry weight across all interactions among four genotypes and their corresponding nitrogen rates (Table 2). However, during the 2010 season, there were significant differences among the nitrogen rates. Genotype 707A1 x 4280 at nitrogen rate $120 \mathrm{~kg} \mathrm{ha}^{-1}$ produced more plant dry weight, andhad significantly greater plant dry weight than $606 \mathrm{~A} 1 * 2304$ at N0 kg ha ${ }^{-1}$ and 2301 at N80 $\mathrm{kg} \mathrm{ha}^{-1}$ (Table 2).

\subsection{Grain Yield}

Due to the high seed loss from insect feeding and bird damage, optimum yield potential was estimated using a regression formula by Pudelko et al. (1993) based on head length. Because of similarities in yields obtained in 2009 and 2010, the yields were pooled. Genotype LHB08 at $0 \mathrm{~kg} \mathrm{ha}^{-1}$ and $120 \mathrm{~kg} \mathrm{ha}^{-1}$ nitrogen gave the highest yield, followed by LHB08 at $40 \mathrm{~kg} \mathrm{ha}^{-1}$ and $80 \mathrm{~kg} \mathrm{ha}^{-1}$ nitrogen (Table 3). It can be concluded that genotype LHB08 have better overall genetic potential for yield (average yield 6,159 $\mathrm{kg} \mathrm{ha}^{-1}$ ) across all treatments in comparison to the other three genotypes that were used in the nitrogen rate experiment. This high yield is similar to findings by Sarr et al. (2008) where peal millet achieved a yield of $6,041 \mathrm{~kg} \mathrm{ha}^{-1}$. It can further be concluded that pearl millet possesses high $\mathrm{N}$ use efficiency as a result of which it can produce high yields with $\mathrm{N}$ supplementation.

Although it is traditionally known that pearl millet yields appreciably with low nutrient availability, there are conflicting reports of yield response to high fertilizer application rates (Gascho, Menezes, Hanna, Hubbard, \& Wilson, 1995). In Eastern Nebraska, a significant increase in grain yield of pearl millet with application rate of 78 $\mathrm{kg} \mathrm{N} \mathrm{ha}{ }^{-1}$ was observed by Maman, Mason, Galusha, and Clegg (1999) and Limon-Ortega et al. (1998). According to Menezes, Gascho, and Hanna (1999), highest pearl millet yield resulted from N rate of $112 \mathrm{~kg} \mathrm{ha}^{-1}$. On the other hand, N-fertilizer applications have also been reported to be associated with decreased grain yield under late planting situations, drought conditions or high levels of mineral $\mathrm{N}$ in soil. Residual nitrate has been reported to account for the inconsistencies in the response of pearl millet to nitrogen fertilization (Maranville \& Sirifi, 1995). Kennedy et al. (2002) also reported inconsistencies in pearl millet yield in response to nitrogen application in Louisiana (USA).

\subsection{Correlations}

Plant height at 63 and 77 days after planting were positively correlation. Plant height at 49, 63 and 77 days after planting had a direct reflection on the grain yield produced (Table 4). This means that the taller the plants, the more yield they produced and vice versa.

Table 4. Correlation among plant height, number of plants booting, number of heads and estimated yield

\begin{tabular}{ccccccc}
\hline & $\begin{array}{c}\text { Plant height } \\
\text { at 49 DAP }\end{array}$ & $\begin{array}{c}\text { Number } \\
\text { of plants } \\
\text { booting at 49 } \\
\text { DAP }\end{array}$ & $\begin{array}{c}\text { Plant height at } \\
\text { 63 DAP }\end{array}$ & $\begin{array}{c}\text { Number of } \\
\text { heads at 63 } \\
\text { DAP }\end{array}$ & $\begin{array}{c}\text { Plant } \\
\text { height at 77 } \\
\text { DAP }\end{array}$ & $\begin{array}{c}\text { Estimated } \\
\text { yield }\end{array}$ \\
\hline Plant height at 35 & 0.42638 & 0.00498 & 0.54996 & 0.29716 & 0.15647 & 0.23926 \\
DAP & 0.0004 & 0.9799 & $<.0001$ & 0.0171 & 0.2169 & 0.0611 \\
Plant height at 49 & 64 & 28 & 64 & 64 & 64 & 62 \\
DAP & -0.12266 & 0.63310 & 0.01551 & 0.35595 & 0.49544 \\
Number of plants & 0.5341 & $<.0001$ & 0.9032 & 0.0039 & $<.0001$ \\
booting at 49 DAP & 28 & 64 & 64 & 64 & 62 \\
& & -0.12703 & 0.64393 & -0.34674 & -0.44627 \\
Plant height at 63 & & 0.5195 & 0.0002 & 0.0707 & 0.0196 \\
DAP & & 28 & 28 & 28 & 27 \\
& & & 0.07528 & 0.49266 & 0.55257 \\
Number of heads at & & & 0.5544 & $<.0001$ & $<.0001$ \\
63 DAP & & & 64 & 64 & 62 \\
& & & & -0.21212 & -0.30577 \\
Plant height at 77 & & & & 0.0924 & 0.0157 \\
DAP & & & & 64 & 62 \\
& & & & & 0.49007 \\
\end{tabular}


Head length and the number of heads at the time of harvest were found to be negatively correlated. Previous work reporting a negative correlation between head length and number of heads in sorghum has been reported by Ezeaku and Mohammed (2006). Plants with fewer heads produced longer heads resulting in higher grain yield. Number of heads and the number of tillers were positively correlated. Therefore the higher thenumber of tillers, the higher the number of heads produced by each genotype. Also, the number of heads was positively correlated to the plant dry weight (Table 5).

Table 5. Pearson's correlation for number of heads, tiller and plant weight for pearl millet genotypes and combined nitrogen treatments for 2009 and 2010

\begin{tabular}{cccc}
\hline & Number of heads & Number of tillers & Plant weight \\
\hline \multirow{3}{*}{ Head length } & -0.11668 & 0.10792 & 0.00364 \\
& $<0.0001$ & 0.0002 & 0.8999 \\
& 1171 & 1193 & 1195 \\
Number of heads & & 0.49646 & 0.38643 \\
& & $<0.0001$ & $<0.0001$ \\
Number of tillers & & 1175 & 1175 \\
& & & -0.03296 \\
& & & 0.2544 \\
& & & 1198 \\
\hline
\end{tabular}

\section{Conclusion}

Field production of pearl millet for grain in the southeastern United States is feasible based on the results of this study. Although, agronomic response varied significantly based on seasonal climatic conditions, pearl millet production in this region is still advantageous due to pearl millet's genetic pre-disposition to perform under stressful growing conditions including drought and low nitrogen.

We observed in this study that an increase in nitrogen rate did not increase the head length and the number of heads produced. Since these variables are primary contributors to grain yield, therefore, lack of response to increased nitrogen rates means this input can be eliminated, thus reducing cost of production while achieving optimal yields, provided that an appropriate cultivar is selected. Cultivars with higher number of heads and tillers were associated with high plant density and shorter plants. These characteristics are desirable for forage and grazing. However, genotypes with larger head size such as LHB08 would be more favorable for grain production. Increasing rates of nitrogen did not have significant impact on plant biomass and grain yield, but positively affected plant height of specific cultivars. Selection of genotypes for specific location and response to fertility should preclude other management inputs in wide-scale production of pearl millet based on needs for either biomass or grain yield.

\section{Acknowledgement}

We thank Dr. Jeffrey P. Wilson (retired) of the Crop Genetics and Breeding Research Unit, USDA -ARS, Tifton, GA, for guidance and providing the pearl millet lines used in this study. The funding for this research was provided by USDA-NIFA under 1890 Capacity Building Grants Program.

\section{References}

Andrews, D. J., Majumdar, J. V., \& Doggett, H. (1975). Pearl millet program. ICRISAT, Hyderabad, India.

Baker, R. D. (1993). Millet Production-Guide A-414. New Mexico State University.

Baltensperger, D. D. (2002). Progress with proso, pearl and other millets. In J. Janick, \& A. Whipkey (Eds.). Trends in New Crops and New Uses (pp. 100-103). Alexandria: ASHS Press.

Chohan, M. S. M., Naeem, M., Khan, A. H., \& Kainth, R. A. (2006). Performance of pearl millet (Pennisetum americanum L.) varieties for forage yield. Journal of Agricultural Research, 44, 23-27.

Davis, A. J., Dale, N. M., \& Ferreira, F. J. (2003). Pearl millet as an alternative feed ingredient in broiler diets. Journal of Applied Poultry Research, 12, 137-144.

Dewey, L., Hanna, W., Buntin, G. B., Dozier, W., Timper, P., \& Wilson J. P. (2009). Pearl millet for grain. University of Georgia Cooperative and Extension Bulletin, 1216. 
Ezeaku, I. E., \& Mohammed, S. G. (2006). Character association and path analysis in grain Sorghum. African Journal of Biotechnology, 5(14), 1337-1340.

Gascho, G. J., Menezes, R. S. C., Hanna, W. W., Hubbard, R. K., \& Wilson, J. P. (1995). Nutrient requirements of pearl millet. In I. D. Teare (Ed.), Proceedings of First National Grain Pearl Millet Symposium, Tifton, GA (pp. 92-97). 17-18 January. University of Georgia and USDA Spec. Publ., Tifton, GA.

Hancock, D. W. (2009). Pearl Millet. The University of Georgia College of Agricultural and Environmental Sciences Manual.

Henry, R. J., \& Kettlewell, P. S. (1996). Cereal Grain Quality. London: Chapman \& Hall. http://dx.doi.org/10.1007/978-94-009-1513-8

Kennedy, C., Bell, P., Caldwell, D., Habetz, B., Rabb, J., \& Alison, M. A. (2002). Nitrogen application and critical shoot nitrogen concentration for optimum grain and seed protein field of pearl millet. Crop Science, 42, 1966-1973. http://dx.doi.org/10.2135/cropsci2002.1966

Khairwal, I. S., Yadav, S. K., Rai, K. N., Upadhyaya, H. D., Kachhawa1, D., Nirwan, B., ... Srikant (2007). Evaluation and identification of promising pearl millet genotype for grain and fodder traits. SAT eJournal, $5(1)$.

Limon-Ortega, A., Mason, S. C., \& Martin, A. R. (1998). Production practices improve grain sorghum and pearl millet competitiveness with weeds. Agronomy Journal, 90, 227-232. http://dx.doi.org/10.2134/agronj1998.00021962009000020020x

Maas, A. L., \& Hanna, W. W. (2006). Cover Crop Affects Nitrogen Response of Pearl Millet in a Strip-till System Grain Production (p. 124). ISMN 47.

Maas, A. L., Hanna, W. W., \& Mullinix, B. G. (2007). Planting date and row spacing affects grain yield and height of pearl millet Tifgrain 102 in the Southeastern coastal plain of the United States. Journal of SAT Agricultural Research, 5(1), 1-4.

Maman, N., Lyon, D. J., Mason, S. C., Galusha, T. D., \& Higgins, R. (2003). Pearl Millet and Grain Sorghum Yield Response to Water Supply in Nebraska. Agronomy Journal, 95, 1618-1624. http://dx.doi.org/10.2134/agronj2003.1618

Maman, N., Mason S. C., Galusha T. D., \& Clegg, M. D. (1999). Hybrid and nitrogen influence on pearl millet in Nebraska: yield, growth, and nitrogen uptake and nitrogen use efficiency. Agronomy Journal, 91, 737-743. http://dx.doi.org/10.2134/agronj1999.915737x

Maranville, J. W., \& Sirifi, S. (1995). Pearl millet response to N fertilizer in silty clay loam soils of Eastern Nebraska. In I. D. Teare (Ed.), Proceedings of First national grain pearl millet symposium (p. 109). Tifton, GA. 17-18 January. University of Georgia and USDA Spec. Publ., Tifton, GA.

Menezes, R. S. C., Gascho, G. J., \& Hanna, W. W. (1999). Nitrogen fertilization for pearl millet grain in the Southern Coastal Plain. Journal of Production Agriculture, 12, 671-676.

Muchow, R. C. (1988). Effect of nitrogen supply on the comparative productivity of maize and sorghum in a semi-arid tropical environment leaf growth and leaf nitrogen. Field Crops Research, 18(1), 131-43.

Mullins, G. L., \& Reeves, D. W. (1994). Residual phosphorus and pH effects on pearl millet grain production. Proceedings: First National Grain Pearl Millet Symposium.

Pale, S. (2002). Planting time and row spacing for pearl millet [Pennisetum glaucum (L.) R. Br.] and grain sorghum [Sorghum bicolor (L.) Moench] in Nebraska, M.S. Thesis. University of Nebraska: Lincoln, Nebraska. Agronomy Journal, 95, 1047-1053.

Pale, S., Mason, S. C., \& Galusha, T. D. (2003). Planting time for early-season pearl millet and grain sorghum in Nebraska. Agronomy Journal, 95, 1047-1053. http://dx.doi.org/10.2134/agronj2003.1047

Pandey, R. K., Maranville, J. W., \& Bako, Y. (2001). Nitrogen Fertilizer Response and Efficiency for Three Cereal Crops in Niger. Communications in Soil Science and Plant Analysis, $32(9$ \& 10), 1465-1482. http://dx.doi.org/10.1081/CSS-100104206

Pudelko, J. A., Wright, D. L., \& Teare, I. D. (1993). A method for salvaging bird damaged pearl millet research. Fla. Agric. Exp. Stn. Res. Rep. No., NF 93-12,1-11.

Raghunatha, G., Jagannath, M. K., Krishnamurthy, K., \& Rajashekara, B. G. (1972). Differential behavior in tillering and heading in oat, barley and wheat. Indian Journal of Agricultural Science, 42, 1057-1060. 
Sarr, P., Badiane, A., Yamakawa, T., Guisse, A., Khouma, M., \& Sene, M. (2008). Effect of pearl millet-cowpea cropping systems on nitrogen recovery, nitrogen use efficiency and biological fixation using the $15 \mathrm{~N}$ tracer technique [electronic resource]. Soil Science and Plant Nutrition, 54(1), 142-147. http://dx.doi.org/10.1111/j.1747-0765.2007.00216.x

Sedivec, K. K., \& Schatz, B. G. (1991). Pearl Millet-Forage production in North Dakota. R-1016.

Singh, R. J. (1969). Hybrid vigor in pearl millet. Indian Journal of Agricultural Sciences, 40, 11.

Singh, R., Singh, D. P., \& Tyagi, P. K. (2003). Effect of Azotobacter, Farmyard Manure and Nitrogen Fertilization on Productivity of Pearl Millet Hybrids (Pennisetum glaucum (L) R. Br) in Semi-Arid Tropical Environment, GAGS 49(1), 21-24. http://dx.doi.org/10.1080/03650340301498

Tchala, A. W. (1989). Factors influencing grain yield in pearl millet Pennisetum glaucum (L.) R. Br. Doctorate Dissertation, University of Georgia.

Teare, I. D., Wright, D. L., \& Pudelko, J. A. (1994). Pearl millet stages of development in relation to planting date and available water. Fla. Agric. Exp. Stn. Res. Rep, No. NF-94-11, 1-12.

Timper, P., \& Hanna, W. W. (2005). Reproduction of Belonolaimuslongicaudatus, Meloidogynejavanica, Paratrichodorus minor, and Pratylenchusbrachyurus on Pearl Millet (Pennisetum glaucum). Journal of Nematology, 37(2), 214-219.

Wilson, J. P., McAloon, A. J., Yee, W., McKinney, J., Wang, D., \& Bean, S. R. (2006). Biological and Economic Feasibility of Pearl Millet as a Feedstock for Ethanol Production. In J. Janick, \& A. Whipkey (Eds.), Issues in New Crops and New Uses (pp. 56-59). Alexandria: ASHS Press.

\section{Notes}

Note1. This paper is part of the work carried out by Eric Obeng for M.S. research thesis at the Alabama A \& M University.

Note2. Joint contribution of Department of Biological and Environmental Sciences, Alabama A \& M University and Agricultural Research Station, Fort Valley State University and is published as journal no. 655 of the Alabama Agricultural Experiment Station, Alabama A \& M University. 